\title{
特集号によせて*
}

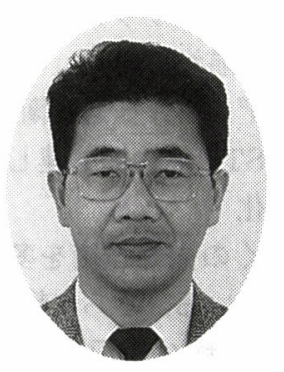

富 田洋 司**
電気・電子システム研究委員会においては本学会 誌1992年 2 月号 (VOL. 27NO. 2 ) で「船舶電気電 子システム/機器の最先端技術特集号」を発刊した。 同特集号において当時の先端技術を紹介した，それ らはコンピュータやエレクトロニクス応用技術によ る海図, 制御システム, 支援システム, 及び超電導 推進, GMDSS，等であった．電子海図，大規模な コンピュータによる制御・監視統合システム, 現代 制御理論を用いた高速船の姿勢制御またGMDSSの 実運用, と確実に実用化がなされている言えよう。 ただ超電導推進においては現在のところ実用化の計 画は聞こえていないがもう少し将来的に考えてよい のではないかと考える.

現在の技術レベルに達する迄の歴史について思い つくところを述べる.

1) 金華山丸における自動化は現在の自動化船の始 まりと言われている. 当時では先端技術をとりいれ かつ時と共に進歩してきた技術を採用し今日のよう にコンピュータ及びエレクトロニクス応用技術によ る高度な自動化が実現されている，その目的は機関 部の無人化運転を実現させかつ乗組員を減らすため の自動化, 制御システムと言う位置づけではなかっ たかと考える. 船舶の安全運航を確保するための方 策は, 近年のタンカー事故が発端となった 2 重化船 殼構造対策に代表されるようにハード面のみで解決 されるのではなく，いわゆるソフト面での対策が必 要であると言われている. 船舶の安全な運航を達成 するためには推進機関, 航海装置, 荷役機器, 等を いかに有用に扱えるかという課題であると考える. それには乗組員の持つ高度な運転, 運航知識をさら に支援し船の状況を適切に判断し，衝突や座礁を回

$*$ 原稿受付 平成 9 年 7 月 2 日

**正会員 川崎重工業(神戸市中央区東川崎町 3 丁目 1 1)
避する装置, 或いは事前に保守整備を行い故障を未 然に防ぐのを支援する装置, 故障を的確に判断する のを支援する装置, いわゆる支援装置を要求する方 向にもあると考える.

2) 外航船では乗組員の混乗化が計られつつある中 で自動化装置は従来レベルではあるが外国人の乗組 員にも容易に馴染めるシンプルなシステムの導入が 望ましいとの考えもある. 省人化或いは乗組員の負 荷を軽減するためのワンマンブリッジ，それを実現 するため各船級協会規則の充実とそれを支援する装 置の商品化が計られている.

3 ) 内航船では乗組員不足之高齢化に対応して省力 化及び小人数運航を目指した内航近代化船の実現が 計られている.

このような背景を踏まえ近年の当研究委員会にお ける種々の調查研究を紹介しておく.

• GMDSS導入に関する調查研究

・船舶総合防災システムに関する調査研究

・パワーエレクトロニクス応用機器搭載時におけ る電源設備の留意点

・新エネルギーの船舶等への応用に関する調查研 究一太陽光発電に関する調查研究一

・ワンマンブリッジ

・自動システム, モニターシステムに関する調査 研究

・電気設備の電磁環境に関する調査研究

・電気推進システムの調查研究

・制御, 計測装置, 表示装置の独立性に対する考 え方の調查研究

がある. 又世の中の当研究委員会に関係する主な技 術トピックスを紹介する.

・32bitマイクロコンピュータの商品化

- AI技術応用の運航装置及び故障診断装置の商 品化 


特集号によせて

・統合ブリッジシステム・電子海図とこれに関す る航海装置

・デジタル伝送式衛星通信装置

・STC条約に関連した操船シミュレータの商品 化

等多くの先端技術を多用したものが現実のものと 成っている.さらに超電導電磁推進船「やまと」の 実証実験の完了,「テクノスーパーライナー (TSL)」の実験終了, 燃料電池による舶用電気推 進システムの研究と大きな研究が実施された.

現在船舶に求められているのは船舶の安全運航, 人に優しい船，地球に優しい船，と考える．金華山 丸からの船そのものの進歩とはちがった，もっとグ ローバルな方向に向けられているのではなかろうか.
無人化された自律制御型の船, 化石燃料から脱却し た動力源をもつ船，等々の夢をみる．このようなこ とを考えると船舶関係者だけ，ましてや電気関係者 だけでは解決されない多くの問題があると思う. 我々の先輩諸氏の努力に習い 1 つ 1 つ実現させ着実 に前進させられることを期待する.

本特集号は現在使用されている或いは将来使用可 能な種々の先端技術と, 規則・規格等の動向を紹介 することで今後の動向を示唆したつもりである. 今 後新しいシステム・技術を検討する方々の参考なれ ば幸いである.

この特集号を発刊するに当たり著者の方々及び関 係者各位に厚くお礼を申し上げる. 


\section{英国ヤードでのFPSO現地工事 に立会っで}

\section{1. 派遣の経緯}

当社長崎造船所にてSHELL/SBM社向けFPSO (Floating Production Storage Offloading)〔船 名：ANASURIA」のBARGE部を建造し, 1996 年 1 月引き渡したが, 同年, 4 月からは英国での TOPSIDE（プロセスプラント）部搭載工事を開始 し，10月のOIL-INまでに全工事／コミッショニ ング終了というタイトな工程となっていた.この ように時間的にも厳しい条件の中で, TOPSIDE 部搭載工事とコミッショニングを, 遅帯無く遂行 する目的で英国, AMEC (AMEC PROCESS \& ENERGY LTD）社へ派遣されたのでご紹介する. 工程表を図 1 , 英国・北海周辺の地図を図 2 に示す.

\section{FPSOの要目と外観}

主要目を表 1 に, 北海にえい航されるFPSOを図 3 に示す.

\section{3. 業務の概要}

現地では電気, 計装のエンジニアとして次の業務 を遂行した。

・引き渡し時の, 残工事の対応 各工事毎に JOB CARD (変更依頼図として, どの樣な電線を どの樣に敷設するのか, また, 工事の際の感電防止 として, 何処のブレーカーを遮断させるか具体的に 詳細位置を指示する，）を作成し，AMECに施工 依頼するとともに, 施工完了の確認を行う。

引き渡し時の残工事609件. JOBCARD作成250件

* 原稿受付 平成 9 年 6 月 13 日

**三菱重工(姝長崎造船所 (長崎市飽の浦町 $1-1$ )
（電気，計装関係は131件）

支給品のフォロー 引き渡し時の未搭載品の入荷 状況を調查し, ストックハウスでの現品の確認を行 う. 確認後, AMEC作業者へアイテム毎に取り付

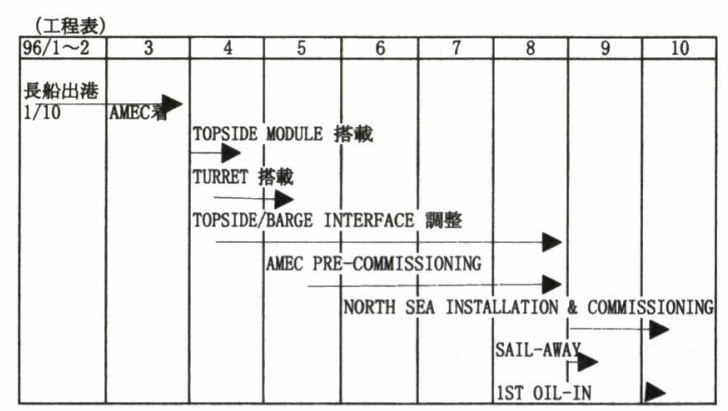

図 1

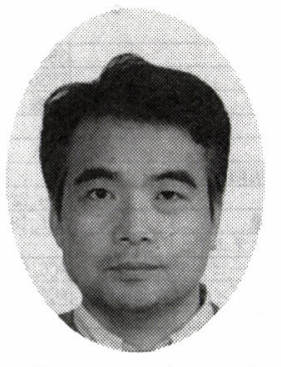

増 本 克 則** 


\section{表 1 FPSO主要目}

\begin{tabular}{|c|c|}
\hline 船主 & SBM/SHELL \\
\hline 船種 & FPSO(Floating Production Storage Offloading) \\
\hline 稼働油田 & 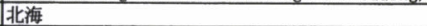 \\
\hline 水深 & $88 \mathrm{~m}$ \\
\hline \begin{tabular}{|c|c|c|} 
組員 \\
\end{tabular} & $55 人$ \\
\hline 船級、規則 & DOE , HSE \\
\hline 主寸法 & Lpp $225.8 \mathrm{~m} \times$ B $44.8 \mathrm{~m} \times$ D $23.8 \mathrm{~m}$ \\
\hline 載貨重量 & $131,181 \mathrm{t}$ \\
\hline \multicolumn{2}{|l|}{ 発電システム } \\
\hline ガスターピン発電機 & AC6, $600 \mathrm{~V}, 10,000 \mathrm{KW} \times 3$ 基 \\
\hline 非常用ディーゼル発電機 & AC450V, 750KWX1基 \\
\hline カーゴポンプ & 油圧駆動/サプマージド型、 $1,400 \mathrm{~m} 3 / \mathrm{hX} 7$ 基 \\
\hline デッキクレーン & ディーゼル駆動油圧式、12tonX2基 \\
\hline カーゴホースリール & 油圧駆動、8m径、巻き取り速度 : $6.5 \mathrm{~m} /$ 分X1基 \\
\hline
\end{tabular}

けの指示を行う.

・船主追加要求, 及びルール要求への対応.

・プレコミッショニング（北海でのコミッショニ ングの事前調整) の対応 直接電気機器の調整, 操 作は出来ない為, 現地コミッショニングチームへの アドバイス, 及び不具合が発生した場合の対策の指 導を行う。

\section{4. 現地に於ける電気関係工事の主な問題点}

- FIRE \& GAS/ESD SYSTEM 各機器のイ ンターフェイスはCAUSE AND EFFECT, I / O LISTにより管理されるが, プロジェクトとして の明確なフィロソフィーを確立されていない為に最 終段階に於いて, 大混乱した.この為, 約40点の I / O及び電線追加が発生した。

- FIRE DETECTOR, GAS DETECTORの シールド線の結線及び, 電線グランドの施工の造船 所の処置が悪く, HSE (Health \& Safety

Executiveの略称, 英国政府の安全所轄官庁）のコ メント発生したので, AMECにて手直しを行った. (FIRE DETECTOR約140個, GAS DETECTOR 約50個)

・各キャビンのレセプタクルの变更POWER SOCKET (居住区, 機関室) がLIGHTING CIR CUITから給電されており, LRS, IEEルールに違 反しているとコメントあり, レセプタクルのタイプ を変更し（一部分はヒューズ付きを追加）対処した. （レセプタクルの変更, 追加分は約260個）

・プレコミショミングの対応 プレコミッショニ ングチームは本船（特にBARGE部）のシステム を完全に理解した者が担当になっていない為, 機器 調查時, 不明な点があればしょっちゅう事務所に聞 きにくる. そこで図面で指示するが, それでも理解

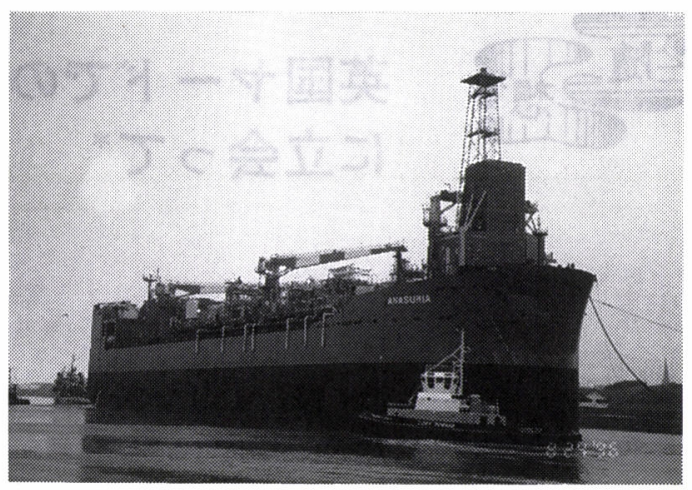

図 3 北海にえい航されるFPSO

してくれない為, その度に現場に出向き対応した。 FIRE PUMPがFIRE \& GAS PANELから遠隔 制御できない不具合が発生し，この時はFIRE PUMPメーカーも既に帰国しており，インター フェイスの取り合いが不明と言うことで, 急きょ対 応することになった. FIRE PUMP CONTROLLERのプログラム コントローラーの プログラムを読み, インターフェイスの 1 点, 1 点 のチェック要領を指導して, 無事問題解決をした. この樣に, プレコミッショニングは機器メーカーの エンジニアがいる時に実施されるとは限らない為, 問題が発生した場合はメーカーの立場となり, 早急 に対応しなければならない状況にあった。

\section{AMECヤード概要}

・AMECヤードは, ドックも船台もない

FABRICATIONヤードであり, クレーンはモービ ルタイプで何処でも移動可能である.

・勤務時間（定時）月： $7: 30 \sim 16: 00$

$$
\text { 火〜木: } \quad 7: 30 \sim 18: 00
$$

金: $7: 30 \sim 15: 00$

昼休みは30分, $10: 00$ と $15: 00$ に約15分のコーヒー タイムがあり, 全員下船するが時間前にタラップの 手前で行列を作って待機しており, 作業再開まで約 30〜45分のロスタイムになっている. 不能率, 低効 率の一因になっている.

・ JOB CARD制度 工事アイテム毎にJOB CARDが必要. これを発行しないとAMECシステ ムは稼㗢しない. 英国造船業の遅れの要因になって いると思われる.

・PERMIT WORK制度 安全面は非常に厳し 
くPERMIT WORK制度がある.これはAMEC以 外の業者が船上で作業をする場合に行う手続である が，度を越えた徹底した安全管理となっており，更 に組織が官僚的で書類作成，許可取得に多大な時間 を要する為，工事遅れの要因にもなっている．英国 メーカーでもうんざりする有樣でSHELLですらコ ントロール不能であった. 当社所掌の工事に対して は常時立会/監視が必要であった. 即ち,メーカー エンジニア 1 人での作業は許されなかった.

・ユニオン 多くの業種毎の組合があり, すぐス トライキをするらしい，全体をまとめる管理者が非 常に少なく，前後工程を意識して仕事する気は全く ない. その為, 機器本体のチェック後に, パイプラ イン（海水, 清水等）のバルブ, フランジ状況を確 認せずに運転し，パイプから海水が漏れ電気機器を 冠水させるという事故が発生した事もあり，システ ム物の取り扱いは問題多し.

・安全 PERMITWORK制度で分かる様に非常 に厳しい反面, 安全と言えない作業光景も目にした。 船側外壁のクリーニングをゴンドラを使用せず， 1 本のロープで空中に吊り下げられたまま，ジェット ホースを脇に抱きかかえアクロバットさながらの作 業をしたり，梯子は木製で，固縛はロープで簡単に 縛る程度で使用するなどの危険行為が見受けられた。 現地作業の服装も日本とは違い, ヘルメットは顎ひ もなし, 目の保護のためのメガネ装着（これは徹底 している），脚絆は装着しない，安全靴はブーツタ イプ, 安全ベルトは基本的に不要で, 使用するとき のみ申請して受け取る. ベルトはパラシュートタイ プ（パラシュートに傘がないもの）を使っていた.

・サブコン 電気関係はJAMES \& SCOTT社 が担当していたが, 改造工事は手慣れており, 盤内 の改造も彼ら自ら施工し, 緊急に電気艤装品を要す る場合も自ら購入する. 作業に時間を掛けることも あるが, 工事の仕上がりは美しく芸術的である. 作 業者は皆陽気で, 鼻歌を歌いながら作業している光 景をよく見かけた．作業は少なくとも 2 人以上で組 んでおり施工する.

・日常の生活 仕事が終わってからの楽しみと言 えば, 夕食. まず, 食事の前には, みんなでパブに 行き, ビールで乾杯. 残念ながらアルコールに弱い 小生によっては多くは飲めず，パブの雾囲気を楽し むと言う程度であった。
食事はイタリア料理, インド料理, 中華料理, タイ 料理と飽きないように日替わりで食事をした. ただ, 食事に時間がかかり, ホテルに帰るのは, 遅く殆ど 11時近くになった.

滞在期間中, 運動不足になり, 運動不足解消にジョ ギングをしたり, プールやジム, サウナに行った. また, 滞在も長期になると毎日の洗雏も大変になり, 日本でも行った事のなかったコインランドリーに行 き, 店のおばさんから 1 から教えて貪うなど, 海外 で初めての経験をした.

\section{6. 海洋構造物建造工事の特徵}

最後に海洋構造物建造工事の特徵をAMECヤード での経験に基づき以下にまとめる.

・ OFFSHOREでは常識では考えられない要求も 発生し, 時間がないからとか, 工事が完了したから との理由は，通用しない。

AMEC引き渡し間近の要求は次のとおり.

居住区にパワーソケット10個追設.

ESD VALVE開閉表示をDCS及びESDに （約20点）追加及び電線追加.

GALLEY機器交換 (皿の寸法が小さい, 機器 はSHELL手配）それに伴う電線追加.

LOUNDRY機器の交換. (洗濯機の容量が小 さい, 機器はSHELL手配)

・他ヤードでPRODUCTIONを搭載する場合は, BARGE側の残工事を絶対残してはならない.

現地ヤードの方針には従わなければならず，他ヤー ドに持ち込んだ場合の費用は $4 \sim 5$ 倍以上にアップ し, 非能率的である.

・ OFFSHOREルールはSHIPルールと根本に於い て, 相違しており, HSE要求に対して, 現地では これに従わなければいけない状況にある.

SHIPルールベースで設計すると膨大な工事発生と なり，設計ステージでのOFFSHOREルールの十 分な把握が必要である.

以上のとおり, 現地工事は多々な問題が山積されて いたがAMECとの協業により，無事引き渡しでき たと共に, OIL-INも問題なく終了したことに満 足している.

北海油田で本船が大いに活躍することを期待しつつ 本稿を締めくくりたい. 


\section{船舶電気電子技術の今後の課題*}

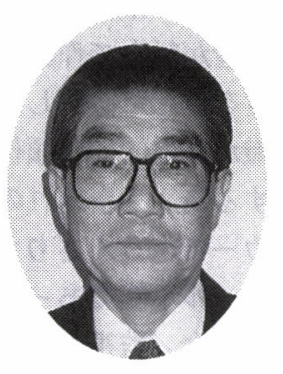

武田幸男**
電気電子システム研究委員会は平成 2 年（西暦 1990年）に電気・自動化・エレクトロニクスの3 研 究委員会が合併した委員会 (当時委員長堀籠教夫東 京商船大学教授) で, 船舶の電気・制御・情報系設 備技術を総括し, 新技術の調査研究・開発状況・将 来予測等の報告やシンポジウムを行って, 船舶の安 全性の向上に寄与することを目的としている.

平成 3 年秋の学術講演会で, 最初の活動としてシ ンポジウム「舶用電気電子システム/機器の最先端 技術」 ${ }^{1)}$ を開催した. クリスタルハーモニーの電気 推進設備, 超電導電磁推進船, GMDSS, ジェット フォイルの自動姿勢制御, 舶用プラントの情報管理 システム, ワンマンコントロールブリッジの 6 テー マについて活発な討論が行われたが, 特に将来予測 の質問が多かった事が印象に残っている.

これらのテーマの多くはその後の委員会活動でも 引続き取り上げられ, その成果の一部が本年度春期 の学術講演会でのシンポジウムで紹介され, 今日, 実用期にあるこれら先端電気電子機器の問題点を確 認すると共に将来への展開が期待された.

20 世紀後半の船舶電気系技術は新技術の開発之省 エネルギー技術への寄与, 及びコンピュータ制御・ 情報システム機器の普及に貢献する所が大きかった が，21世紀を直前にして船舶電気技術には地球環境 の保護を基盤とする各種の工学技術との協調が一層 求められる事になると思われる. そのような視点か ら旧聞に属する点もあるが, 直流電源・電気推進・ 安全システムについて所感の一端を述べたい.

* 原稿受付 平成 9 年 5 月 21 日

**名誉会員 神戸商船大学名誉教授

\section{1. 直流電源}

\section{(a)太陽光発電装置 ${ }^{2)}$}

舶用電源としての太陽光発電装置の利用には(1)救 命艇の電源, (2)非常用電源 (バッテリ) の充電, (3) インバー夕使用による船内一般負荷への給電などが ある。

太陽光発電用セルの交換効率は住宅用で17\%のも のが市販されているが3)，これを船内電力用に使用 する場合には $1 \mathrm{~kW}$ あたり $7 \mathrm{~m}^{2}$ の設置場所が必要に なる，船型によっては，例えば自動車運搬船の上部 構造部などの樣に航走時の抵抗障害にならない設置 場所が考えられるが, 海上での使用であるから耐塩 性などの特性が加わる.

(b)燃料電池 ${ }^{4)}$

各種の燃料電池方式は研究段階が進み, 一部の方 式については実用化運転が始まっているが, 船舶で はメタノールを燃料とする燃料電池電源やLNG船 のタンク侵入熱により放出される天然ガスを利用し た燃料電池電源が研究途上にある. 発電効率が $60 \%$ に達する固体高分子型PEFC (Polymer

Electrolytic film Fuel Cell）が有望と見られてお り, 電解質での陽イオン交換の作動温度が $60 \sim 100$ ${ }^{\circ} \mathrm{C}$ と低い.

PEFCでは, メタノール $\left(\mathrm{CH}_{3} \mathrm{OH}\right)$ は蒸発器で ガス状になり水蒸気と共に改質器に送られ, 改質器 内部で

$$
\mathrm{CH}_{2} \mathrm{OH}+\mathrm{H}_{2} \mathrm{O} \rightarrow 3 \mathrm{H}_{2}+\mathrm{CO}_{2}
$$
の化学反応によって生じた $\mathrm{CO}_{2}$ ・水素の混合ガスが 燃料電池の陽極に送られる. 混合ガスには $1 \%$ の COガスが含まれており，これが電池内部の白金を 劣化させるのでCO除去技術の成否がPEFC型燃料 電池の寿命の鍵になる.

PEFCの電解質は薄膜状をしており, 湿気を含ん 
だ状態で動作するので，混合ガスを湿らせるための 加湿器が必要である. そして陽極に送られる水素之, 陰極に送られる空気によって, 電池から得られた直 流電力はインバータで交流に交換され系統に繫がる. その際の廃棄物は改質反応によって生じる $\mathrm{CO}_{2}$ 之電 池の化学反応によって生じる水 $\left(\mathrm{H}_{2} \mathrm{O}\right)$ だけであ る.

21世紀には水素燃料の比重が高まると予測される. 1995年の阪神大震災では六甲アイランドにある関西 電力新エネルギー実験センタの燃料電池システムは 損害軽微で, 激震に耐えぬいたことが印象的であっ た. 水素漏洩による爆発抑制技術は水素冷却交流発 電機で確立しているが, 燃料電池システムの実用化 には発電システム全体の防爆構造について実証害験 を重ねる必要があろう.

\section{(c)超電導電磁発電 ${ }^{5)}$}

超電導電磁推進船「ヤマト $1 」 は 1996$ 年三菱神戸 造船所で建造され, 磁束密度 $4 \mathrm{~T}$ (Tesla), 電極 電流2, $000 \mathrm{~A}$ の時, 理論值に近い7.5ノットで航走し たが, この推進装置を速い海流中に固定する事に よって, 発電と水素発生装置に利用することが可能 である.この超電導発電装置は21世紀のクリーンエ ネルギーシステムとして大きな可能性を持っている，

高温超電導素子の開発は確実に進展しており, 既 にへリウム温度で10テラス以上の高磁場が現実と なっている.「ヤマト1」では鞍型の超電導電磁コ イルが採用されたが, アメリカ, 中国 ${ }^{6)}$ などでは比 較的製作が容易なトロイダル巻線構造やヘリカル巻 線構造についての研究報告がある.

超電導電磁発電の実用化に当たっては, コイルの 最適構造についての基礎的な研究が待たれると共に, 「ヤマト $2 」 の$ 実現を期待したい.

(d)電気二重層キャパシタ (Electric Double Layer Capacitors) ${ }^{7)}$

最近, 電気二重層キャパシタが話題になっている. $\varepsilon$ を電解液の誘電率, $\delta$ を電極表面からイオン中心 間での距離（電気二重層の厚さ），S 電極表面積 とすると, 電気容量 C は次の式で表される.

\section{$\mathrm{C}=\int \varepsilon \cdot(1 / 4 \pi \delta) \cdot \mathrm{dS}$}

固体電極之溶液の接触する界面では, 極めて短い 距離を隔てて正, 負の電荷が対向して配列して電気 二重層を作るので, その電気容量 Cは20〜 $40 \mu \mathrm{F} /$ $\mathrm{cm}^{2}$ 之極めて大きく, ファラッドオーダの小型大容量 コンデンサが得られる. 直流内部抵抗は数 $10 \mathrm{~m} \Omega て ゙$,
$1 \mathrm{kHz}$ においても約 $1 \Omega$ 之小さく，構成材料に重金 属を含まないので環境污染の心配がない. エレベー 夕のように回生エネルギーと駆動エネルギーが交替 に行われるような負荷に最適で，既に自動車の制動 エネルギーをコンデンサに眝蔵し，スタート時の電 動機駆動用電源として実用されている.

電気二重層キャパシタを蓄電池に代わる大電力眝 蔵装置としての研究が始まっている. ノイズ吸収に も効果的で, $\mathrm{DC} / \mathrm{DC}$ コンバータやインバータ電 源の入力電圧の安定化用として定着しているが, 船 舶への応用はこれからという所である.

(e)直流システム

水素吸蔵合金の性能も日々に向上しており，直接 動力発生装置としての水素エンジンの登場も魅力的 な将来テーマであるが，水素直接供給型燃料電池は システム構成が簡明で, 21 世紀の電気エネルギー源 の主流になると予想されている.

今日の電動力負荷は交流を直流に一旦交換した後, インバータで再度交流交換して可変速運転を行うも のが増加している. また, 家庭電気機器やパソコン などの情報装置の電源は交流を直流変換し, 更にイ ンバー夕交換を行って後, 適切な直流に変圧して使 用している. このエネルギー変換の度に電力損失が 発生するから，直流システムが普及すれば損失が少 なくなる．また，現在問題になっている高周波電力 の人体に及ぼす影響や，交流電力の高周波歪み（パ ルス妨害）の問題も直流システムとすることによっ て問題を局限することが出来る.

これらの直流システムではインバータを通じて船 内交流負荷に電力を供給するが，かならずしも50／ $60 \mathrm{~Hz}$ とする必要はない。 むしろ周波数を高くして モータの高速回転によってポンプの小型化を促進し, ポンプ重量の低減を図るべきであろう.

\section{2. 電気推進船 ${ }^{8 ） 9 １ 0 ） ~}$}

電気推進船は経済性の点で劣るとされ, 客船や砕 水船などのいわゆる特殊船の推進方式として見られ てきたが, 最近では貨物船やフェリー, タンカーな ごの船舶に拡大しており, 欧州においてこの傾向は 顕著である:これには,

(1) 複数のデイーゼル発電機によって電力供給さ れるので, 故障対策が立てやすい.

(2) 電力変換装置は静止機器であるから故障が少 
なくメンテナンスが容易である.

（3）低速運転時のプロペラ駆動効率が良い.

(4) 操縦性に富み, ワンマン制御に適している.

など，その長期にわたる経済運航性が次第に船主間 に浸透してきた結果と思われる. 更に,

（5）発電装置は定速運転なので，SOxやNOxに よる排ガス污染を抑制すると共に燃焼効率が向 上する.

（6） 2 軸プロペラ駆動方式は安全性が高い.

など，デイーゼル電気推進船では船舶事故を含め, 海洋環境污染の心配が極めて少ないことが注目され ている.

船舶設計面に於いても，

（7）機関室の多層化によって機関室容積が減少し, 載荷容量が増加する.

（8）大容量回転機（同期電動機／誘導電動機）の 高圧化によりモータの小形化が進む.

（9）発電機エンジンをパッケージ化すれば, 電力 システムはメンテナンス不要であるから小人数 運転が出来る.

(10) 高速モー夕と減速歯車を組み合わせると, 低 速モー夕採用時と比較して電気系の損失が $10 \%$ 減少し, 船尾形状がスリムになって船体抵抗を $7 \%$ 以上減少出来たという報告 ${ }^{11)} も$ もる.

特に今後益々進む小人数操縦化に於いても, 乗組員 の負担の少ない船舶であることの事例として, 次の 特徵を指摘しておきたい.

(11) 推進システムが簡潔で, 発電機エンジンのシ リンダ数増加という問題点はあるが, 機関室補 機数が減少する.

(12) 火災や爆発に対する不安感が少ない.

(13）船の振動・騒音が減少するので, 居住環境が 良くなる。

(14) 安全システムの構築が容易である.

\section{3. 安全システム ${ }^{21}$}

\section{(a)低コストの船舶}

現在, 就航する貨物船は少数技術者で運航される 八イテク設備の船舶之, 多数船員で運航される局所 自動化の船舶に 2 分され, 後者が圧倒的な数である.

この為, 国際的に安価な船舶の建造が続いている が, 最近数年間の船舶事故の増加は異常であって, 海難による海洋・海岸の環境污染は年々に増加して
いる.

船舶構造よりも船員の技術レベルに問題があると する意見もあるが，建造コストは多少高価になって も長期無事故の収益性を重視する船主が増えており, 安全な海運産業をめざしての総合的な取組が始まっ ている.

船舶の建造には「使い易くて, 安全で, 安価な船 舶」が目標であるが，「安価な船舶」が強調され易 い. その結果, 船員によっては「使い難くて, 危険 で, 安価な船舶」に乗船していると感じる場合があ る.

多数の他国籍船員が混乗する船舶では, 操縦装置 ・エレクトロニクス機器・情報通信装置などの機能 性と安全性に関する徹底した教育が必要であるが, これを視野にいれて, 地球と船員にとって経済性の 高い安全な船舶とは何かが21世紀の命題であろう。

(b)KISSマークシップ

お断りしておくが, KISSマークシップというの は私の造語である. 本学会の友好姉妹学会である IMarE (英国舶用機関学会) の学会誌MER

（Marine Engineers Review）1997年 1 月号に挟 み込まれていた学会後援の会議の標題“KISS

(Keeping It Simple for Seamen)”を読んでい るうちに浮かんできた言葉である．F 種モー夕につ いている “HOT” マークからの連想で, 真っ赫な キスマークがベったりと付いた広告に刺激されての ことである.

1997年 3 月20-21日, ロンドンで開かれたので, 既にその内容についてご承知の方も多いと思われる が, 提案の趣旨は「今の船主は操縦・管理・修繥が シンプルな推進機器を望んでいる. 機器製造者及び 造船所はどのように答えるのか.」であり,この為 に「船主の視点からのKISSの要望を確かめる」た めに，「船舶のシンプルな操縦と管理を達成するた めに行われた推進機器の開発技術」を多数のエンジ ンメーカーと共に検証するイベントであるとしてい る.

筆者は常々, 機器の研究開発に当たって

“Simple is Best”を信条としているが, 船舶の建 造は造船造機技術者之商船士官との密接な対話の再 構築から始まるとしたKISSの率直な企画に賛同し たい．そして船員の使いやすい船舶の普及を願い, これら船員に優しい船舶を “KISSマークシップ” と呼びたいと思う。 
船舶電気系の技術開発に関わってきた筆者のイ メージでは, KISSマークシップの推進装置は,

(1) メンテナンスフリーのパッケージタイプの定速 デイーゼル機関を原動機とする多数台の発電装置 を主機関とし，

(2) サイクロコンバータなどのパワーエレクトロニ クス機器による可変速モー夕を推進モータとし,

(3) ワンマンコントロールが容易な制御システムか ら成る運動性能の良い 2 軸電気推進船である.

更に夢を広げれば，原動機は燃料電池発電によっ て静止機器化し，モータには理論的に高調波トルク ゼロの直流無整流子モー夕 $(T B M)^{13)}$ の 2 軸電気 推進船である.

\section{4. まと め}

結論として, 船員にとってシンプルな推進システ ムとは, 操縌の容易さ, 保守管理の容易さ, 修繥作 業の容易さを感じさせるシステムである.

それには，自動化システムの区分化や，単純な操 作の積み重ねによる操縦システムの構築など, 現状 の見直しから出発する事になるが, 故障が少なく乗 組員が安心できる 2 軸電気推進船が長期経済性の点 からも安価な船舶として船舶関連技術者から認知さ れる事を期待している.

本文では船舶の電気動力系技術を中心に述べたが, これらの実用化には制御・情報処理技術の運用が必 要で, この面からのシンプルな船舶運航システムの 確立についてより一層の討論が行われることを期待 したい.

\section{参考文献}

1) 電気電子システム特集号: 舶用機関学会誌Vol. 27, No. 2, 1992

2 ）日本舶用機関学会電気電子システム研究委員会報告 No.295: 太陽光発電システムの船舶への適用に関す る調査研究, 平成 7 年 12 月

3 ) シャープ会社資料 : 住宅用太陽光発電, 平成 9 年 4 月

4 ) 野村雅宣, 他: 燃料電池の開発現状と技術課題, 舶 用機関学会誌Vol. 29. No. 2. 1994.

5 ) 岩田章: 超電導電磁推進システム技術, 舶用機関学 会誌Vol. 24. No. 2. 1989.

6 ) Ciwen Shat他: An Outline of the Superconducting MHD Ship Thruster Study in China, 第 3 回国際船舶電気学術会議（IMECE上海）論文集, 1997. 5. 27-30.

7 ）吉田昭彦：エネルギーをバックアップする大容量コ ンデンサ, 電気学会誌, Vol,117. No. 3, 1997.

8 ）舶用機関学会電気電子システム研究委員会報告No. : 電気推進装置に関する調查研究, 平成 9 年 6 月.

9 ) Electric Propulsion-The Effective Solution, I Mar E Conference Proceedings Part 1. Oct.1995.

10）佐藤孝雄, 他: 漁業調査船「開洋丸」の電気推進シ ステム, 舶用機関学会誌Vol. 27. No. 3. 1995.

11) Laurent MAZODIER-CEGELEC-DEI/ FRANCE : Electric Propulsion of Ships, 33 rd I. S. E. S. A. G. M, 14th May1996.

12）馬淵祐二：自動化計装システムに対する運航者の要 望, 舶用機関学会誌Vol.24. No. 2. 1989

13）武田幸男, 他: 複巻励磁サイリス夕直流機, 舶用機 関学会誌, Vol.24. No. 10. 1989. 


\section{無人船の可能性*}

少し前のことになるが, 日本造船学会の運航シン ポジウムが開かれた時 ${ }^{1}$, 最後にきて有識者から「日 本船舶が日本人船員で国際競争力を保持するために は，船舶当たり 4 名で運航する必要がある」之聞い たことが今でも印象に残っている．当時は近代化船 そしてパイオニアシップが運航され, 少しでも日本 人による運航を目指して努力していた時代である.

しかし，その後の円高等が急激に押し寄せ 1 ドル 80 円台を迎え，ついにそのような努力を消滅させたよ うに記憶している．そのシンポジシウムでも無人化 による商船がほんのわずか話題になったが, 別の主 要なテーマの方に移り余り触れられずに討論は終了 したが，そのことを今でも残念に思っている.

いつも無人船の話題が出ると,「乗組員は不要で すね」となりその後の話題がひとつ弾まない. どう も無人船は余り芳しくない話題の一つである. 特に, 筆者の勤める大学では, 自分で自分の首を絞めてい るようで, 気兼ねのする話題のひとつではある. し かし, 最近の社会的経済的変化によって無人船の実 現可能性を検討出来る状態まできたように思われる がどうであろうか. 技術的には十分実現可能であろ うと推察できるが, 技術だけでは実現は不可能であ る事例は枚挙にいとまがない，だとすれば，無人船 の実現を阻止している要因はなにか.これを検討す れば，なにが無人船実現で最重要かわかるであろう が，さてどこからどんな手を打てばよいか明確でな い，もしうまく無人船の検討方向がわかり，そこか ら説得力のある議論が展開でき，かつ関係者がその 気になればこれにこしたことはない，誰がいかにし てそこまで持っていくかと言う点が最も難しい，そ こで改めて無人船を話題にしたいが，大きく分けれ ば，無人船そのものとそれを取り巻く環境や条件之 なり，それらについて概略的に考察したいと思う。

$*$ 原稿受付 平成 9 年 6 月 11 日

**正会員 東京商船大学教授 (江東区越中島 2-1-6)
さて, 肝心の無人船で重要なシステムといえば, もちろん立場によって異なるが，ここでは船舶推進 機関システムとしよう. 従来, 主機関でもそれを支 援する補助機関でも, 単体として極めて優れた機能 特性等を持つが，それらでシステムを構成すると， 各要素の間に具合の悪いことが起こることが指摘さ れてきた.このような状況や条件等が発生しないよ うに，はじめからシステム化を目指した要素設計が 要求されてきたし, その傾向は強まってきた. しか し, 今後はこの傾向を更に数段押し進めることが重 要であろう．80年代からメカトロニクスやロボット という新しい概念が導入されてきたが，実際にはま だいろいろな問題があり, 電気と機械が本当に融合 して有機的になるには多くの時間が必要であろう.

少し話題は変わるが, 石井前会長がIM arEで講 演された内容が会誌に掲載されている2).それによ ると舶用ディーゼル機関はメーカーが異なっても機 関の構造に相違がなくなりつつあるということであ る. 70 年代当初 (1973), つまり第 1 回のISME TOKYOが開催される以前に船舶の需要予測に関す る委員会があり，そこで舶用主機関の部品の規格な ごを世界的に統一するための条件などを検討してい た時代が急に思い出され，30年といえども隔世の感 がする. 当時石油ショックを経験していないことも あり，影気のよい予測が行われたように思う。しか し，73年に第一次石油ショックが突如として発生し， 予測がいかに難しいものであるか身を持って体験し た. 今後ディーゼル主機関がメーカーごとに相違が なくなると, 今後はその運用や使用法等に重点が 移ってくるだろうと石井前会長は予測されておられ る. つまり, 主機関の運用, 故障診断, 保全や保全 支障等が重要になってくるということである. 本会 誌でもこれらに関して多くの実績が報告されてきた し, 今後の大きな課題の一つでもある. その場合, コンピュータの利用は不可欠であり, それをいかに 運用管理, 故障診断, 保全等に利用すべきかも, 今 


\section{無人船 の可能 性}

後のこれまた大きな課題であろう.

一方，今まで船舶省人化を可能にした条件などに ついて多くの報告があるが，偏見も入るがやはりコ ンピュータの利用が重要であり, 今後船舶制御管理 への応用技術がキーポイントであることは, 今まで 多くの研究や現場からの報告実績からも明らかであ ろう. 従って, 今後もコンピュータ, エレクトロニ クスの技術やシステム等が大切であることは分かる が, 問題は船舶のどの分野あるいはどの管理部門に 応用したら，本当に合理的にコンピュータを利用で きたと言えるかが明確でない点にある. しかし, 学 会で長い間議論となってきた船舶の省人化が，その ターゲットとして最もふさわしい問題のひとつであ ると推測されるし，さらに会誌でも無人船を含む夕 イトルの報告などが昭和50年代にも見出せる ${ }^{3)}$ 。も ちろん，その当時における無人船のイメージと現在 のそれは大きく異なるかもしれないが, 省人化船の 話題そのものが誰もがその背後に無人船が近い将来 実現するはずという思いがあったと言っては言い過 ぎであろうか.

次に，無人船の実現化を図るためには船舶そのも のも大切であるが，同時に無人船を取り巻く環境の 整備, つまり，無人船全体をまとめてシステムとし て取り扱うことが不可欠である. 従って, 無人船も そのシステムの中の一要素であるということを強調 したい，言い換えれば，無人船とそれに関連する分 野も同時に考虑して, 全体として有機的システムと なるように構築する必要がある. システムは個々の 要素の良さを引き出し, 機能的に弱い要素であって も構成によって, 優れた特性を発揮すること等は理 論的にも経験的にも知られている. 一方, システム の機能を有効に発揮させ, その維持管理等を図るた めには，システムを支えるバックアップ体制が重要 であるが，このような事実は航空宇宙関連のシステ ムに見られる. また, 自動車メーカが生産性向上の ためにロボットを導入した際に，ロボットの保守・ 点検のために多くの人手が要求されたという事例は よく知られている。そして, システムが複雑になる ほど，システムに対する保全，つまた保守・改修・ 点検等の強力な実施があること, すなわち, 強力な バックアップ体制が存在しなければならないことは 承知の通りである.

以上のようなことから無人船では, 強力な保全体 制が必要であるが，もちろん，保全支援体制の構築
は，無人船の出現に必要だからというだけではなく， 現在の船舶でも不可欠なことは明らかである.ただ, 現在の船舶はそれほど陸上からの保全支援を要求し ないから一見不要に見えるだけである．無人船の場 合は, 現在とは比較にならない位優れた陸上からの 保全支援体制や保全技術等を要求することになろう. 従って, 無人船の評価はそれを支える保全管理技術 や支援体制のあり方等によって大きく左右されると 推測される.もちろん，現在でもこのようなことは 認識されているが，それを実現するだけの経済的社 会的パワーが不足していると考えられる. しかし, その要因がどのようなものか不明だが，何らかの社 会的インパクト等が発生すれば, 無人船の発生する 可能性は十分有り得るような気がする.

さて，昨今出現した船舶管理会社が，来るべき船 舶の保全や管理等のあり方を予言しているように思 われる. 船舶乗組員がそのような管理会社に吸収さ れ, 現在の規模を遙かに上回る保全管理システムの 体制化が進み, 全く新しい船舶之就労体制が構築さ れる可能性を含んでいよう，すなわち，船舶の支援 体制が逆に多くの雇用を作り出す可能性を大いに秘 めているということである.このような体制を実現 させる上で重要なことは無人船を受け入れる環境の 整備, 具体的には港湾施設そのものに保全整備体制 を取り入れることである.つまり，船舶の支援体制 の主力施設等を船舶の活躍する場に極めて接近した あるいはその中に設置することが大切であり，次に 強力な支援体制システムの設置が無人船の実現，管 理等のために最も不可欠であろう。しかし, 現在の 港湾施設等をみると，それらは陸船間の物流のため には都合よく構成されているが，船舶の保全支援体 制からは極めて不備である. 従って，今後の港湾施 設の抜本的改革が求められるであろう.

最後に，あと 5 年足らずで 21 世紀となる. さらに 戦後（1945年）から約50年亡言う長い年月の間に, 大きな枠組みの変動や社会の変化等に伴う大幅な流 通革命等も世界中が経験してきた。 また，今世紀の 半ばからコンピュータの急激な台頭とその著しい進 歩発展は，その誕生から考えると当時の予想を遙か に越えるものであった．現在，コンピュータはその 適用領域も拡大し，日常生活から極めて専門的技術 や通信まで広げ，今後の工業技術に関するキーテク ノロジーとしてますます君臨するであろうが，それ らの技術を応用し無人船の実現を少なくとも来世紀 
の初頭にはその可能性は十分にあると推測される. その理由として, より効率を追求した新しい物流シ ステムの構築の模索, そのシステムの安全性や保全 性の検討, 社会的経済的フレームワークの変動等よ゙ れ一つとっても, 無人船への引き金となると推測さ れる.

いずれにしても無人船が船舶の持ついろいろな課 題や問題等を悉く解決する手段であるということは なかろう. しかし，このような夢の実現が海事関連 事業とそれに携わる人々に, さらには陸上の産業の あり方も変えるような大きな刺激となると思われる.
今後活躍を期待される海運, 造船や海事に携わる若 い技術者の舊起を切に望みたい。

\section{参考文献}

1) 運航性能研究委員会: 第 8 回シンポジゥム 船の運 航自動化技術, 日本造船学会 (平成 3 年12月).

2 ) 石井: 船機誌, $32-1$ (平成 $9-1$ )， 1 .

3) 平田その他 5 名 : 舶機誌, 13-12, (昭和53-12), 918. 